International Journal of Life Sciences
Available online at www.sciencescholar.us
Vol. 4 No. 1, April 2020, pages: $42-49$
e-ISSN: 2550-6986, p-ISSN: $2550-6994$
https://doi.org/10.29332/ijls.v4n1.392

\title{
Cocoa drying system using ancestral sliding
}

\author{
Ingri Catherine García Castro ${ }^{\text {a }}$, Telly Yarita Macías Zambrano ${ }^{\text {b }}$
}

Manuscript submitted: 27 November 2019 Manuscript revised: 09 December 2019, Accepted for publication: 30 January 2020

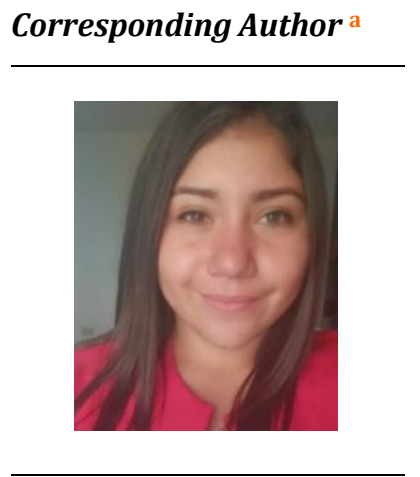

\section{Keywords}

ancestral;

cocoa;

dryer;

sliding;

solar energy;

\begin{abstract}
The decrease in the application of ancestral practices such as the drying of cocoa in traditional slides is a problem that affects small grain producers in terms of the price of the product, which is mostly sold in slime. It is intended to design an ancestral slide for cocoa drying so that ancestral knowledge of cocoa drying is recovered by promoting a fair price for cocoa that benefited for small producers. An experimental field methodology was applied. Results were obtained in 24 hours of drying light $7 \%$ humidity at an average temperature of $34^{\circ} \mathrm{C}$, a parameter that allows preserving the quality of the grain during storage and without risk of deterioration due to the appearance of fungi. A solar-powered dryer was traditionally called slides used by small producers of cocoa in the province, where they can use materials from their environment and obtaining a dryer with a capacity, drying hours and percentage of humidity similar to the use of a dryer with conventional energy, without paying for the grain drying service in an industrial dryer.
\end{abstract}

International Journal of Life Sciences (C) 2020. This is an open access article under the CC BY-NC-ND license (https://creativecommons.org/licenses/by-nc-nd/4.0/).

\section{Contents}

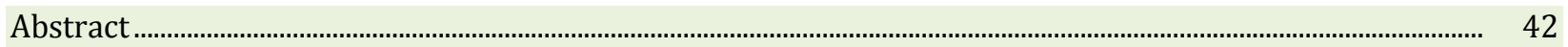

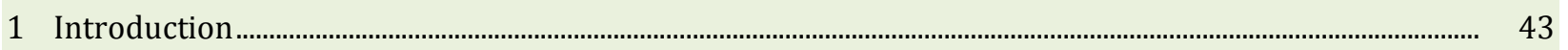

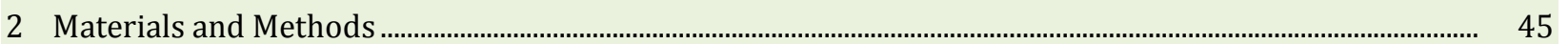

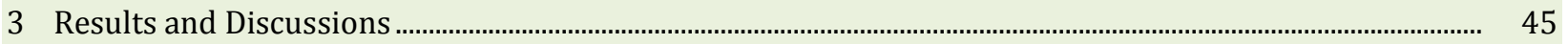

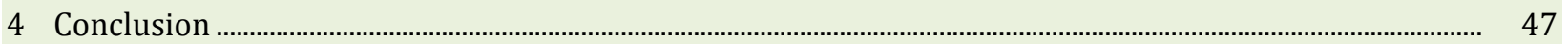

Acknowledgments........................................................................................................................................................... 47

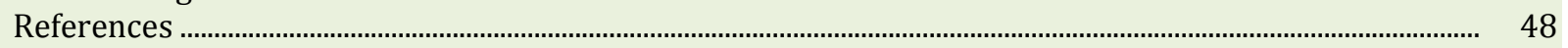

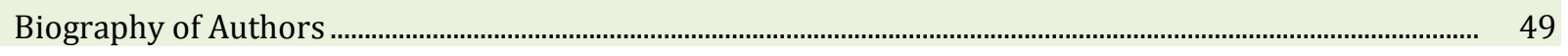

${ }^{a}$ Instituto Superior Tecnológico Paulo Emilio Macías, Portoviejo, Ecuador

b Instituto Superior Tecnológico Paulo Emilio Macías, Portoviejo, Ecuador 


\title{
1 Introduction
}

The research problem focuses on the loss of traditional knowledge about the use of so-called slides (artisanal cocoa dryers) in rural peasant sectors, which have been replaced by gas and electric energy dryers. Part of this traditional knowledge promoted cocoa activity within the producing farms, improving the commercialization of the final product, which has currently decreased since the cocoa bean is mostly marketed in drool, so they receive a lower sale price than the benefited cocoa (Maydasari, 2016; Zambrano et al., 2019). The objective of this research is focused on the design of a cocoa drying system using the ancestral slide. So, if the cocoa dryer is designed using the ancestral sliding, it will be possible to recover traditional knowledge, including improving the process of benefiting the grain in small producers.

According to Miguel Estrada, WJ and Romero Castellano, XG (2011) cited by (Macías, 2018), in their publication comment that:

\begin{abstract}
A beautiful legend tells that Quetzalcoatl, the god of the moon and winds, discovered the tree of cocoa in the bright fields of the children of the sun. He gave it to the men who called him "The Food of Gods"... According to the chronicles was Hernán Cortez, one of the first to taste his taste. Quetzalcoatl before leaving for Tapallan prophesied that he would return "where the sun rises." In the year indicated in the Aztec calendar as "Ce-acalt" (1519 of the Christian era), just when the first Spaniards landed on the coasts of Mexico. This coincidence meant for the Aztecs the announced return of their banished God. And the reception of the Spaniards as divine beings. Moctezuma offered visitors the most sacred drink for the Aztecs in a glass of gold: chocolate, consisting of a mixture of cocoa, ground corn, pepper, various spices and natural aphrodisiacs.
\end{abstract}

In the publication of Jimbo \& Arboleda (2016), it is said that cocoa is a fruit of tropical origin, its tree has small flowers and long petals; its fruit is elongated woody, and appears at the culmination of trees and under its branches. Depending on the type of cocoa they can be yellow, white, green or red. The grain is covered with a sugar-rich pulp with which juice can be made, and the grain transformed into chocolate has a pleasant flavor. In Ecuador, there are two types of cocoa, the fine aroma cocoa characterized by its aroma and flavor sought by chocolate manufacturers, and CCN-51 cocoa, recognized for its high performance.

The cocoa bean requires complying with a chain of very particular processes before becoming the basic raw material for the production of chocolate. Among the fundamental stages is the beneficiary of cocoa, roasted, ground, pressed and shell. It is known as the beneficiary of the cocoa bean at the stages of harvest, fermentation, drying, cleaning, selection, and storage of the grain. The fermentation and drying stages are the most critical within the process chain, the organoleptic qualities acquired by the grain depend on them (Parra, 2017).

Also, drying is an essential operation in the process of the benefit of cocoa because the grain must contain about $6 \%$ moisture so that its storage is prolonged for several months and can prevent attacks caused by fungi and bacteria. Before the drying process begins, the surface moisture is distributed evenly throughout the cocoa bean surface and in its respective mucilage, but it can be easily removed. Considering an average of $60 \%$ of initial moisture in the grains, up to $85 \%$ of moisture can be extracted at the beginning of this operation (Liendo, 2005).

According to the study of Bela (2013), with the name of beneficiary, a series of operations are known to which the natural agricultural product is subjected to convert it into a marketable article; In the case of cocoa, these operations consist of fermentation, drying, cleaning, selection, and classification, together with complementary tasks such as polishing and polishing and the old roofing, as the purpose of the beneficiary is to convert cocoa into a conservable product, which has aroma and flavor qualities that give it all its commercial value for later use in the food, fat and pharmaceutical industries.

The main objective of the drying process is that the cocoa finishes developing the chocolate flavor that began during fermentation and the almonds acquire the brown or brown color typical of the properly fermented and dried cocoa (Parra, 2017). A drying method is the artificial one, which mainly produces the transformation of the grain in the post-harvest and, in turn, is the procedure that requires the most attention not to affect the quality, since the energy used in the production process of Grains, drying consumes about

Castro, I. C. G., \& Zambrano, T. Y. M. (2020). Cocoa drying system using ancestral sliding. International Journal of Life Sciences, 4(1), 42-49. https://doi.org/10.29332/ijls.v4n1.392 
$50 \%$, and taking into account factors of quality and energy consumption, you can appreciate the importance of its correct realization (Tinoco \& Ospina, 2010).

In the artificial drying method, the quality of the dehydrated product is generally superior if a good process technology is selected although it has a high cost of installation, both for the drying chamber and for the method used to raise the temperature, for example; boilers, furnaces or air heaters, and the high cost of production in case petroleum-derived fuels or electricity are consumed for heating the air or the product (Gilces \& Sanmartín, 2013). The natural drying method contemplates the effect of air on the cocoa bean; this is the most convenient method since it depends on the climatic conditions of the sector or region. The movement of the drying air is due to the action of the wind, and the energy requested to evaporate the moisture from the almond depends on the drying capacity (moisture absorption) of the air and the direct incidence of solar energy. There are several ways to implement this method; many of these have evolved over time, needs and climatic conditions (Jimbo \& Arboleda, 2016).

Enriquez (2004), called the natural drying of cocoa to the process of drying by exposure to the sun and consists of taking advantage of the heat generated by the sun's rays to slowly and slowly dry the cocoa almonds. With this drying technique, the almonds successfully complete internal biochemical changes, achieving good organoleptic characteristics. This type of drying can be done using lines, which can be constructed in various ways, using wood, bamboo, cement or other refractory materials. In natural drying, grain flips are performed infrequently during the first days and more frequently during the last days of drying. Depending on the hours of sunshine and the intensity of the sun's rays, the process can last between 3 and 12 or up to fifteen days.

One of the techniques of drying in by means of sliding counters or drying counters of different heights and with a wheel system that allows placing a low level of another, in a covered area. The drying surface is made of wood, assembled with side edges that prevent the grains from falling down the sides. The rails where the inns run are metallic and the structure usually in wood, but a more solid structure is required. The roof covering is made of metal tiles (Pérez \& Contreras, 2017).

Solar grain drying is one of the most important applications of solar energy, only heat is required at lowtemperature levels, where the efficiency of the collectors is higher, and in addition, the accumulation of energy is not essential. Natural solar drying in patios is the oldest and most widespread way of using solar energy for drying agricultural products. The natural drying in the courtyards has been progressively decreasing in favor of artificial drying that uses conventional energy, mainly due to the decrease in the drying time, which leads to eliminating the possibility of damage to the product by slow drying and the decrease in the cost of the workforce. When using dryers that use conventional energy, a greater amount of energy is consumed, and a generally high initial investment must be made, therefore, when the process is carried out in dryers that use conventional energy, it may happen that the cost is high (Continuenty, 2013).

The temperature produced by the sun's rays is used to gradually dry the cocoa. This is perhaps the most recommended method because, when dried slowly, the almonds successfully complete the changes to achieve a good flavor. This drying can be done in tendales. The most common in our environment use wood, cane guadua and cement as a drying surface (Camino et al., 2014).

Depending on the climatic conditions, for drying cocoa beans are necessary between 4 and 6 days, but longer periods can cause the appearance of mycotoxins and the development of mold inside the grain, giving adverse results in the taste and smell of old or mold; In any case, the drying process must be complete, and the humidity reduced to a content between 6 and 7\% (Mahecha \& Revelo, 2013). The platforms for sun drying should be placed so that Maximize your exposure to the sun and air circulation for the maximum time per day, in order to accelerate the drying process and also the thickness of the cocoa bean layer for drying should not exceed $6 \mathrm{~cm}$ (40 kg of grains wet per square meter of drying surface), in order to avoid slow or improper drying, and the grains should be turned several times (between five and 10 times) a day to ensure uniform drying (CAOBISCO, ECA, FCC., 2015).

Once the fermentation process is finished, in the first hours of drying the greatest loss of humidity occurs around 52\% (Bermúdez, 2016). According to Núñez (2017), when the beans are too dry, the grains break under minimal pressure during the necessary handling of the bagging. The husk or testa (refers to the cover that protects the cotyledons) breaks easily, depriving the cotyledons against the attack of fungi and insects. The presence of a high percentage of broken grains as a result of the handling of very dry grains represents significant quality defects at the time of marketing. Valdivia (2015), indicates that low drying temperatures 
(below $20^{\circ} \mathrm{C}$ ) would determine longer drying time. On the other hand, high drying temperatures (greater than $60^{\circ} \mathrm{C}$ ) could generate a dry surface layer while the interior would still be wet, preventing the release of acetic acid while inactivating enzymes responsible for a chocolate flavor.

\section{Materials and Methods}

Some of the materials used in the construction of the ancestral sliding for cocoa drying are shown in Table 1, below.

Table 1

Materials used in the construction of the slide

\begin{tabular}{lll}
\hline Quantity & Unit & Material \\
\hline 4 & $\mathrm{U}$ & Pillars \\
6 & $\mathrm{U}$ & Ropes \\
18 & $\mathrm{U}$ & Beams \\
6 & $\mathrm{U}$ & Rods \\
6 & $\mathrm{U}$ & Metal tiles \\
48 & $\mathrm{U}$ & Tables \\
3 & $\mathrm{~L}$ & Nails \\
\hline
\end{tabular}

Source: (García \& Macías, 2019)

The research was used the field for data collection and design of the cocoa dryer, to consequently build it. Wood and cane were used as raw material, with these four sliding drawers of the same material and the metal roof were manufactured. To build the base of the sliding, the four pillars of greater thickness were placed that support the other elements and can support their weight. The dimensions of the design contain $30 \mathrm{~cm}$ in diameter, with a height of $2.50 \mathrm{~m}$ of which $0.50 \mathrm{~cm}$ is placed under the ground to fix the bases of the sliding.

Then 2 double crochet and 6 wooden ropes were placed horizontally, measuring $2.80 \mathrm{~m}$ each to link the entire construction. To make the drawers for drying, 4 double crochets were used that formed a square that is supplemented with a taba on each side vertically forming a $2.85 \mathrm{~m}$ x $2.85 \mathrm{~m}$ box, you should try not to leave spaces at the base of the drawer so that there are no possible leaks of the cocoa bean losing quality, and so with the 4 drawers that will be used, so that these drawers can be extracted out for drying and then to be able to store them, 2 reeds have to be placed in the part bottom of the box horizontally so that it can be removable. The drawers must be installed without interrupting the other, that is to say in different directions, and the last drawer is at the top of the slide so it will be the only one that will not have lower rails, it will only be covered by a double-dropped metal roof of water that will protect the rest of the building from possible rain damage. The construction must be placed in an uncovered space so that there are no obstacles that prevent the entry of sunlight.

\section{Results and Discussions}

The design of the ancestral sliding system for cocoa drying is shown in figure 1, below:

Castro, I. C. G., \& Zambrano, T. Y. M. (2020). Cocoa drying system using ancestral sliding. International Journal of Life Sciences, 4(1), 42-49. https://doi.org/10.29332/ijls.v4n1.392 


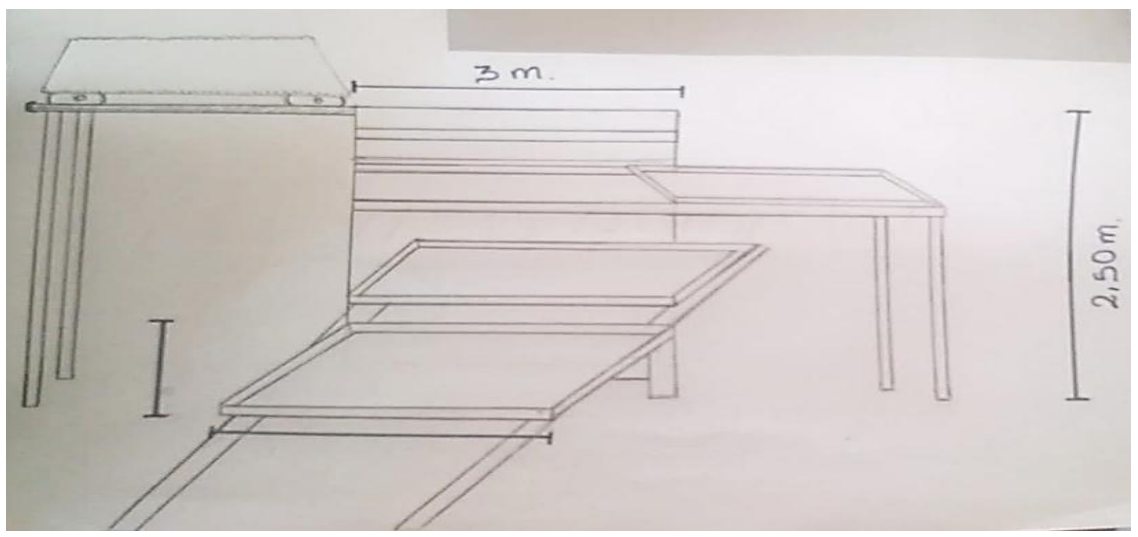

Figure 1. Design of the sliding for cocoa drying

The results of the temperature data collection, humidity, time and mass of drying, both in the sliding system and in a photovoltaic drying system, are shown in Table 2, below:

Table 2

Results of data collection in the ancestral sliding drying system

\begin{tabular}{|c|c|c|c|c|c|c|c|c|c|c|}
\hline \multicolumn{5}{|c|}{$\begin{array}{c}\text { Ancestral sliding drying } \\
\text { Solar }\end{array}$} & \multicolumn{6}{|c|}{$\begin{array}{c}\text { System with drying } \\
\text { photovoltaic solar energy system }\end{array}$} \\
\hline $\begin{array}{l}\text { Tempe } \\
\text { rature } \\
\left({ }^{\circ} \mathrm{C}\right)\end{array}$ & $\begin{array}{l}\text { Humidity } \\
(\%)\end{array}$ & $\begin{array}{l}\text { Daily } \\
\text { drying } \\
\text { time } \\
\text { (hours) }\end{array}$ & $\begin{array}{l}\text { Total } \\
\text { drying } \\
\text { time } \\
\text { (hours) }\end{array}$ & $\begin{array}{l}\text { Drying } \\
\text { mass } \\
\text { (Lb) }\end{array}$ & $\begin{array}{l}\text { Tempe } \\
\text { rature } \\
\left({ }^{\circ} \mathrm{C}\right)\end{array}$ & $\begin{array}{l}\text { Humidity } \\
(\%)\end{array}$ & $\begin{array}{l}\text { Drying } \\
\text { time } \\
\text { (hours) }\end{array}$ & $\begin{array}{l}\text { Drying } \\
\text { mass } \\
(\mathrm{Lb})\end{array}$ & $\begin{array}{l}\text { Drying } \\
\text { time } \\
\text { (hours) }\end{array}$ & $\begin{array}{l}\text { Total } \\
\text { drying } \\
\text { mass } \\
\text { (Lb) }\end{array}$ \\
\hline 24 & 7 & 8 & 24 & 1000 & 43 & 9 & 7 & 300 & 21 & 900 \\
\hline
\end{tabular}

Between results obtained the dryer designed with solar energy called "run iza ancestral" has the capacity to dry 1000 pounds of cocoa for three days, working 8 hours a day, unlike the solar photovoltaic dryer that has a capacity to dry 900 pounds of cocoa for three days with 7 light hours per day, reaching a difference of 100 pounds than if the dryer has traditional solar energy. The traditional solar energy dryer obtained 7\% moisture in the grain, being within the required parameters that are from 6-8\%, with an average ambient temperature of $34^{\circ} \mathrm{C}$ approximately, instead, the photovoltaic solar energy dryer has as a parameter $9 \%$ moisture in the grain, with an artificial temperature of $43^{\circ} \mathrm{C}$.

López (2015), says that currently the drying process is carried out by exposing the grains to the environment, with this ancestral process the drying time is six days, losing production and money, in view of this there are cocoa dryers by forced convection in which a fossil fuel is used, which pollutes the environment in addition to producing a significant expense to the small and large businessman. The drying time is 7 hours for $300 \mathrm{Lb}$ of cocoa. In this investigation, it was established that the drying of cocoa in natural conditions is directly related to the climatic situation in which both the ambient temperature, relative humidity and wind speed are exposed, on this the drying time will depend. Thus, 1000 Lbs of cocoa beans were dried in 24 light hours (3 days).

According to Bermúdez (2016), he mentions that a large number of mechanical dryers have been built, most of which are based on the passage of dry and hot air through the cocoa mass. Artificial drying requires a high investment in equipment and construction. In addition, the cost of fuel for the burner makes drying more expensive, although a few hours of work are needed. The drying of cocoa is very important for the marketing process, which is a disadvantage for small producers who are subject to the prices set by the intermediary, due to the difficulty of owning a drying system, then if you apply a design of Artificial drying is more expensive being out of reach, in addition, the use of fuels contributes to environmental pollution. 


\section{Conclusion}

The ancestral sliding or solar dryer can dry 1000 Lbs (10qq) of cocoa beans in 24 light hours (3 days) with indicators of $7 \%$ humidity and average ambient temperature of $34^{\circ} \mathrm{C}$. The conventional energy dryer It can dry up to 300 Lbs of cocoa beans in 7 hours with indicators of $9 \%$ humidity and temperature of $42^{\circ} \mathrm{C}$. Both the humidity and temperature parameters are established within the normal parameters of grain drying, which results in a Quality grain, suitable for storage and / or commercialization, which promotes an increase in its market price, which consequently benefits the small producer.

When drying in a conventional dryer with capacity for 300 pounds of cocoa beans in 7 hours, the drying time can be doubled to obtain a greater amount of dried cocoa beans, but this demands a greater amount of fuel or electrical energy and hand of work, which generates an additional expense for the producer, which does not occur in the traditional sliding because it does not consume electricity or fuel. The ancestral knowledge of the cocoa-producing farmer plays a fundamental role in defining the drying time of the cocoa bean. It is done manually and visually, testing the grain with your fingers, smelling it and splitting the grain in half to see if there is the presence of moisture inside.

\section{Acknowledgments}

A very special thanks to Ing. Telly Yarita Macías Zambrano, my beloved career teacher and unconditional friend, who has managed to motivate me and guide me on the path of research, and take me to the first place with an Institutional Recognition in the III Contest CREATE INGENIOS 2019 ITSPEM.

To my beloved parents and my Brother, they have been the pillar in my life, the best incentive, and the best medicine, for their immense love and unconditional support. To the land that saw me being born and to which I intend to return to apply all the knowledge learned in my professional training process.

The author is grateful for the Recognition of the authorities of the Paulo Emilio Macías Higher Technological Institute, Lcda. Blanca Celina Meza Cruz, Mgs. and Ing. Gregorio Mendoza Cedeño, Rector and Academic Vice-Chancellor, with the first place in the Contest for the recognition of creativity, knowledge and technical-technological innovation of students in the component of ancestral Knowledge, called CREA INGENIOS 2019; as well as, to institute the graduation modality with the publication of the scientific article.

To the editorial group of the IJLS Magazine for considering this research work for publication, so that this ancestral knowledge of our Montuvia manabita culture is not lost, and, it reaches the knowledge of many people across the planet.

Castro, I. C. G., \& Zambrano, T. Y. M. (2020). Cocoa drying system using ancestral sliding. International Journal of Life Sciences, 4(1), 42-49. https://doi.org/10.29332/ijls.v4n1.392 


\section{References}

Bela, L. (2013). Evaluation of three types of desiccated in the quality of the cocoa bean (Theobroma cacao L.) in the experimental station of Sapecho-La Paz. La Paz, Bolivia: Universidad Mayor de San Andrés.

Bermudez, K. (2016). Postharvest and drying of fine national and aroma cocoa beans for the determination of physical, bromatological and organoleptic profiles. Calceta: Manabí Agricultural Polytechnic High School.

Camino, C., Espín, S., Samaniego, I., Carpio, C. (2014). Comparison of the levels of fat, alkaloids and total polyphenols in almonds of fine national cocoa aroma of different areas of the Ecuadorian coast. Ec. Rev. Food, science and engineering. 22(2), 36-37.

CAOBISCO, ECA, FCC. (2015). Cocoa beans: Quality requirements of the chocolate and cocoa industry. Caobisco

Continuity, J. (2013). Evaluation of an inclined solar dryer with ZEOLITE ABSORBER FOR COCOA BEANS CCN51. Cuenca: University of Cuenca.

Enriquez, G. (2004). Organic Cocoa Guide for Ecuadorian Producers. Ecuador: National Autonomous Institute of Agricultural Research. INIAP.

Gilces, H., \& Sanmartín, F. (2013). Analysis and selection of cocoa drying process and prototype design of a platform type dryer unit. Milagro: Milagro State University.

Jimbo, C., \& Arboleda, F. (2016). Mechanical design and construction of a vacuum cocoa dryer (Theobroma cacao L.) for medium and large producers in the province of Manabí. Guayaquil: Higher Polytechnic School of the Coast.

Liendo, R. (2005). The drying of cocoa. Agronomy of production, 24-26.

López, J. (2015). Development of a system for drying fine aroma cocoa using conventional fuel and renewable energy. Riobamma: Polytechnic School of Chimborazo.

Macías, T. (2018). Comparative analysis of the organic and conventional production of Theobroma cacao in a unit of the Bolivar canton. Portoviejo: Technical University of Manabí.

Mahecha, R., \& Revelo, J. (2013). Agreement of Agreement for a Cleaner Production in the cocoa-organic cocoa subsector. Neiva: COPROAGRO and SENA.

Maydasari, E. (2016). The analyses of factors influencing farmer motivation at cacao farming in North Lombok. International Research Journal of Engineering, IT \& Scientific Research, 2(9), 18-25.

Núñez, J. (2017). Automation of the drying and selection processes of Ecuadorian cocoa preserving sensory characteristics and preventing occupational hazards. Lima: National University of San Marcos - Faculty of Industrial Engineering.

Parra, P. (2017). Modeling of a cocoa drying process using a rotary chamber and hot air flow. Piura, Peru: University of Piura. Faculty of Engineering.

Pérez, M., \& Contreras, J. (2017). Guide to good harvesting, fermentation and drying practices for the production of special cocoa. Bogotá: COEXCA.

Tinoco, H., \& Ospina, D. (2010). Analysis of the cocoa dehydration process for the reduction of the drying time. EIA, 53-63.

Valdivia, R. (2015). Cacaofcaug Fonte: Fundamentals of cocoa drying: https://cacaofcaug.files.wordpress.com

Zambrano, T. Y. M., Castro, I. C. G., Plaza, C. L. M., \& Farfan, R. M. (2019). Recovery of ancestral knowledge for production of traditional Manabí cocoa paste. International Journal of Life Sciences,3(1), 71-78. https://doi.org/10.29332/ijls.v3n1.274 


\section{Biography of Authors}

\begin{tabular}{||l|l||}
\hline \hline & $\begin{array}{l}\text { Ingri Catherine, } \\
\text { Graduated from the Higher Agricultural Career of the Paulo Emilio Macías Higher } \\
\text { Technological Institute. Winner of the First Place in the Ancestral Knowledge } \\
\text { Component of the III Contest for recognition of knowledge, creativity and technical } \\
\text { and technological innovation CREA INGENIOS 2019. } \\
\text { Email: itspem.igarcia1061@gmail.com }\end{array}$ \\
\hline & $\begin{array}{l}\text { Telly Yarita, } \\
\text { Industrial Engineer, specialization Projects. Master in Agricultural Engineering. } \\
\text { Teacher - Researcher. Specialist in Research Methodology and Investment and } \\
\text { Degree Projects of the Paulo Emilio Macías Higher Technological Institute. Project } \\
\text { Advisor in general, Beekeeping and Meliponicultura. } \\
\text { Email: itspem.tmacias@gmail.com }\end{array}$ \\
\hline
\end{tabular}

Castro, I. C. G., \& Zambrano, T. Y. M. (2020). Cocoa drying system using ancestral sliding. International Journal of Life Sciences, 4(1), 42-49. https://doi.org/10.29332/ijls.v4n1.392 